\title{
Forecasting the Development of Horse Breeding Enterprises
}

\author{
Klychova G. S. ${ }^{1,2}$, Faizrakhmanov Dz. I. ${ }^{2}$, Zakirova A. R. ${ }^{2} \&$ Sadrieva E. R. ${ }^{2}$ \\ ${ }^{1}$ Kazan Federal University, Institute of Management, Economics and Finance, Kazan, 420008, Russia \\ ${ }^{2}$ Kazan StateAgrarian University Kazan, 420015, Russia \\ Correspondence: Sadrieva E. R., Kazan StateAgrarian University Kazan, 420015, Russia. Tel: 7-987-275-4848. \\ E-mail:kgaukgs@mail.ru
}

Received: March 19, 2015 Accepted: March 31, 2015 Online Published: April 30, 2015

doi:10.5539/ass.v11n11p302 URL: http://dx.doi.org/10.5539/ass.v11n11p302

\begin{abstract}
In this paper the use of technique for analyzing in horse breeding is studied, which allows to simplify accounting and analytical support of cost management and control the amount of profit as a result of changes in variable costs, selling prices and product mix of the given industry. Mastering this method, an accountant is able to model various combinations of sales, costs and profits, choosing the one most suitable. When planning for a range of products to be realized, the management decision was proposed to withdraw unprofitable product - horse meat from production. As a result of these calculations, it was found that this management decision was correct. The withdrawal of horse meat from production will improve the financial position of koumiss farm and lead to increased profits.
\end{abstract}

Keywords: management accounting, marginal revenue, forecasting, strategy

\section{Introduction}

In present economic conditions, organization management requires formation of objective, timely and authentic information. Specific role is featured for production costs management, as without proper evaluation of the real cost one can not competently manage the efficient production. In modern conditions the role of accounting and analysis increases greatly with emphasis on management. Management accounting system and cost analysis give an opportunity in preparing the accounting and analytical information on the cost for the right management solutions guided by the desire to maximize profits, monitor their performance and efficiency.

This happens due to the ever-changing situation on the market of agricultural products, the advent of new technologies, expanding the list and improving the quality of agricultural activities and services. In the competition for new customers and regional markets industry participants need to pursue a flexible pricing policy, possible only on condition of significant cost reduction. The enterprises of horse breeding sector can achieve their goals and gain competitive advantages through the use of modern methods of cost management, which requires managers to improve the quality of their decisions. It is impossible to make the right decision without having the diverse information about the processes occurring in a controlled structure and external environment. Therefore, the management decisions quality issue in modern conditions has been transformed into the issue of providing the high level of information awareness for management subjects.

\section{Theory}

Management process in modern conditions of the enterprise provided with complete financial and economic independence becomes greatly complicated. Simultaneously, the challenges facing the system of accounting are also changed. Financial accounting is not able to provide with full operative information necessary for planning and control as well as for decision-making in non-standard economic situations. These data can be obtained only in the framework of management accounting (Nixon \& Burns, 2012; Bebbington \& Thomson, 2013).

Currently existing diversity of opinions among writers exploring the problem of essence, role, purpose and place of management and financial accounting, is explained by the complexity of the structure, which in its turn gives rise to the complexity of interactions of the given accounting subsystems in implementation of their basic function - provision of information for making effective modern management decisions. Up to now there is no consensus of opinions regarding its concept as a scientific discipline and practical activity in matters relating to the relationships of management, financial and cost accounting. 
Management accounting is a historically established, scientifically based system, which arose as a result of changes in conditions of production and development of structural forms of organization, this being the determining factor in its value as a basic tool of decision-making (Ittner, \& Larcker, 2002; Matsui, 2013; Quinn, 2014).

One of the main objectives of management accounting is to collect and compile the information needed to make sound management decisions. Based on the information of management accounting the problems of operative and perspective character are solved (Ferreira \& Otley, 2009). Operational tasks include determining the break-even point, production planning, making decisions on pricing. The objectives of the forward-looking statements, those having a long-term strategic importance are: investment, restructuring of business, whether to develop new products.

\section{Results}

The criteria of breakeven point, marginal income, and safety edge can be used for production planning, decision-making on pricing for prediction of enterprise development, in particular, the selection of efficient management strategy of benefits and costs (Bourne, Melnyk, Bititci, Platts, \& Andersen, 2014; Janke, Mahlendorf, \& Weber, 2014). Having analyzed the possible strategies in management of benefits, costs, one can determine the best options for management decisions (increase of price and sales volume of koumiss).

With these five key strategies are possible:

1. Increase in selling prices;

2. Reduction of variable costs;

3. Reduction of fixed costs;

4. Increase in production and sales;

5. Combination of any of these strategies (Hopwood, 2008; Soin \& Collier, 2013).

The process of determining the choice of strategies has been considered by the example of koumiss farm of "YYY" LLC of koumiss production:

1. Increase in selling price by $10 \%$, that is by 3.05 rubles, it will amount to 33.52 rubles for one bottle.

Marginal profit per unit of product is equal to: $33.52-19.03=14.49$ rubles.

Break-even point is:

Fixed costs/Marginal profit per unit $=121,762$ bottles

Safety stock is: $237,668-121,762=115,906$ bottles

Profit is: $115906 \times 14,49=1679477,94$ rub.

Therefore, increase in selling price of koumiss by $10 \%$ will increase profit by $487,377.94$ rubles. $(1,679,477.94$ $-1,192,100)$.

2. Reduction in variable costs by $10 \%$, i.e. by 1.9 rubles, they will be: $(19.03-1.9)=17.13$ rubles per 1 bottle of koumiss.

Marginal profit of 1 bottle of koumiss is: $30.47-17.13=13.34$ rubles.

Break-even point is: $1764330: 13,34=132.258$ bottles

Stock of safety is: $237.668-132.258=105.410$ bottles

Profit is: $105,410 \times 13,34=1406169,40$ rub.

Thus, a decrease in variable costs by $10 \%$ will lead to increase in profits by $214,069.40(1,406,169.40$ $1,192,100)$.

3. The decrease in fixed costs by $10 \%$, that is 176433 rubles, they will be $1,587,897$ rubles.

Margin profit per unit $=30.47-19.03=11.44$ rubles

Break-even point: 1587897: $11.44-138.802$ bottles

Stock of Safety: $237.668-138.802=98.866$ bottles

Profit will be: $98,866 \times 11,44=1131027,04 \mathrm{rub}$

Thus, reducing fixed costs by $10 \%$ will lead to a decrease in profits by $61,072.96$ rubles. $61,072.96$ rubles. $=$ $(1,131,027.04-1,192,100)$. 
4. The increase in production and sales by $10 \%$, that is 23,767 bottles, will make 261,435 bottles. Prices and costs are the same, so the breakeven point has not changed.

Stock of safety is: $261,435-154,359=107,076$ bottles.

Profit is calculated by the power of operating leverage, which equals 2.54 .

Therefore, the profit will increase by $25.4 \%$ from 1,192,100 and will be $302,793.40$ rubles. The above performed calculations are summarized in Table 1.

Table 1. Selection an efficient strategy in management of profits, costs of koumiss production in "YYY" LLC

\begin{tabular}{|c|c|c|c|c|}
\hline Strategy & $\begin{array}{l}\text { break-evenpoint, } \\
\text { bottles }\end{array}$ & $\begin{array}{l}\text { Stock of safety, } \\
\text { bottles }\end{array}$ & $\begin{array}{l}\text { Increase (decrease) in } \\
\text { profit, rub }\end{array}$ & $\begin{array}{l}\text { Strategy } \\
\text { selection }\end{array}$ \\
\hline 1. Starting position & 154359 & 93546 & - & - \\
\hline $\begin{array}{l}\text { 2. Increase in selling price of } \\
\text { koumiss by } 10 \%\end{array}$ & 121762 & 115906 & 487377,94 & + \\
\hline $\begin{array}{l}3 \text {. Reduction in variable costs } \\
\text { by } 10 \%\end{array}$ & 132258 & 105410 & 214069,40 & - \\
\hline $\begin{array}{l}\text { 4. Decrease in fixed costs by } \\
10 \%\end{array}$ & 138802 & 98866 & $-61072,96$ & - \\
\hline $\begin{array}{l}\text { 5. Increase in sales volume of } \\
\text { koumiss by } 10 \%\end{array}$ & 154359 & 107076 & 302793,40 & + \\
\hline
\end{tabular}

Analysis of possible strategies in management of benefits, costs has shown that the most optimal are increasing the price and sales volume of koumiss. Holding these techniques, the accountant is able to simulate various combinations of the volume of sales, costs and profits, choosing the one most suitable.

Production and sales of several product types causes the planning of its range. The structure of the proposed sales of koumiss farm based on market research is: koumiss - $78 \%$, horse meat $-2 \%$, young horses $-20 \%$. The company aims to obtain during the next month 125 thousand rubles of profits. Koumiss farm management needs to know how many units of each product must be sold to get that profit. Let us denote the level of sales of horsemeat for X. Then, based on the current sales structure, sales will amount to:

-koumiss - 39h;

-young horses - 10x.

The price of the products is: koumiss for $1-30.47$ rubles per bottle, horse meat - $67.52 \mathrm{Rs}$. / kg, young horses 69.87 Rs. / kg.

At current prices the revenue from sales can be represented as follows: koumiss $-30,47 \times 39 \mathrm{H}=1188,33 \times \mathrm{X}$; horse meat - 67,52 $\times \mathrm{X}$; young horses $-69,87 \times 10 \mathrm{X}=698,7 \times \mathrm{X}$.

Variable costs per unit: koumiss - 19.03 Rs. / Bottle, horse meat - 84.05 Rs. / Kg, young horses - 59.17 Rs. / Kg.

The total variable costs associated with sale of products are: koumiss $19,03 \times 39 \times \mathrm{X}=742,17 \times \mathrm{X}$; horse meat $84,05 \times \mathrm{X}$; young horses $59,17 \times 10 \times \mathrm{X}=591,7 \times \mathrm{X}$.

Then we use the equation of profit determination.

Revenues from sales - total variable costs - fixed costs

or

Price of product unit $\times X$ - Variable costs per unit of output - Fixed costs

where $\mathrm{X}$ - sales at breakeven point, pieces.

The value of the fixed costs for the coming month is 58,700 rubles. Based on available data it receives the form:

$(1188,33 \cdot X+67,52 \cdot X+698,7 \cdot X)-(742,17+84,05+591,7)-58700=125000$

$1954,55 \cdot X-1417,92 \cdot X=125000+58700$

$536,63 \cdot X=183700$

$\mathrm{X}=342$ 
Thus, for getting the planned profit the enterprise must implement: horse meat $-342 \mathrm{~kg}$; koumiss $-342 \times 39=13$ 338 bottles; young horses $-342 \times 10=3420 \mathrm{~kg}$. The results are summarized in Table 2 .

Table 2. Calculation of expected profits at koumiss farm "YYY" LLC

\begin{tabular}{lcccc}
\hline \multicolumn{1}{c}{ Parameters } & Koumiss & Horse meat & Young horses & Total \\
\hline 1. Salesvolume, units & 13338 & 342 & 3420 & - \\
2. Unitprice, rub & 30,47 & 67,52 & 69,87 & - \\
3. Variable costs per unit of product, rub & 19,03 & 84,05 & 59,17 & - \\
4. Marginal income per unit of product (page 2 - & 11,44 & $-16,53$ & 10,70 & - \\
page 3), rub & & & 36594 & 183527,46 \\
5. Total marginal income (page 4 $\times$ page 1), Rs & 152586,72 & $-5653,26$ & - & 58700 \\
6. Fixedcosts, Rs & - & - & - & 124827,46 \\
7. Operating profit (page 5 - page 6), Rs & - & - & \\
\hline
\end{tabular}

For the purposes of the total cost determination it is required to distribute the fixed costs among all positions of production program. When selecting the base of distribution, one should be guided by analysis of the cost structure. The most accurate result will be obtained, if to choose as cost allocation bases the one having the largest share (Safiullin, Klychova, \& Zakirova, 2014). Since in the cost structure, the largest share belongs to mares' milk and feed, so the cost of the basic materials necessary for manufacture of each type of product will be taken for the base allocation of fixed costs.

Then, on koumiss share the fixed costs will fall in amount of:

$$
58700 \times \frac{259,55}{259,55+14,61+96,44}=58700 \times \frac{259,55}{370,60}=58700 \times 0,70=41090 \mathrm{rub} .
$$

The expected volume of koumiss production - 13,338 bottles, therefore, fixed costs per 1 bottle are: $41090 \div 13338=3,08$ руб.

For horse meat we get $58700 \times \frac{14,61}{370,60}=58700 \times 0,039=2289 \mathrm{rub}$,

and per $1 \mathrm{~kg}: 2289 \div 342=6.69$ rubles

For young horses,

$$
58700 \times \frac{96,44}{370,60}=58700 \times 0,26=15262 \mathrm{rub}
$$

And per unit: $15262 \div 3420=4.46$ rubles.

The calculation results are used for both calculation of the total unit cost of each type of product and determination of profitability of each type (Table 3).

Table 3. Calculation of the total cost and profitability of product unit

\begin{tabular}{lccc}
\hline Parameters & Koumiss & Horse meat & Young horses \\
\hline 1. VariablecostsRs & 19,03 & 84,05 & 59,17 \\
2. FixedcostsRs & 3,08 & 6,69 & 4,46 \\
3. Total cost ( p 1 p 2), Rs & 22,11 & 90,74 & 63,63 \\
4. Price, Rs. & 30,47 & 67,52 & 69,20 \\
5. Profit (page 4 - page 3), rub. & 8,36 & $-23,22$ & 5,57 \\
6. Profitability (page 5: page 3) $\times 100 \%$ & 37,81 & $-25,59$ & 8,76 \\
\hline
\end{tabular}

The carried out calculations indicate the loss of horsemeat production (-25.59\%).

The total income expected from the production of:

-koumiss - $8,36 \times 13,338=111,505.68$ rubles;

-horse meat $-(-23,22 \times 342)=-7941.24 \mathrm{rub}$; 
-young horses $-5,57 \times 3420=19049.40 \mathrm{Rs}$;

Total: $111505.68-19049.40+7941.24=122,613.84$ rubles.

Since horse meat production is unprofitable, then improvement in financial result of koumiss farm the management decision should be taken on removal from production of the given type of product, and the issue of other products remains unchanged. But it is necessary to evaluate the profitability of the remaining types of products and calculate the financial result.

Regardless of production cutbacks the fixed costs remain the same: 58,700 rubles. Let us distribute them among the remaining product types. Principle of distribution is the former. Then the koumiss share will have:

$$
58700 \times \frac{259,55}{259,55+96,44}=58700 \times \frac{259,55}{355,99}=58700 \times 0,729=42798,17 \mathrm{rub} .
$$

or per $1 \mathrm{~kg}$ of 4.65 rubles.

Calculation of the total unit cost of product and determination of its profitability in "improved" production program is presented in Table 4.

Table 4. Calculation of total cost and profitability of products of "improved" production program

\begin{tabular}{lcc}
\hline Parameters & Koumiss & Young Horses \\
\hline 1. VariablecostsRs & 19,03 & 59,17 \\
2. FixedcostsRs & 3,21 & 4,65 \\
3. Total cost $(\mathrm{p} 1+\mathrm{p}$ 2), Rs & 22,24 & 63,82 \\
4. Price, Rs. & 30,47 & 69,20 \\
5. Profit (page 4 - page 3), rub & 8,23 & 5,38 \\
6. Profitability (page 5: page 3) $\times 100 \%$ & 37,01 & 8,43 \\
\hline
\end{tabular}

From "advanced" production program one should expect the following profit: koumiss $-8,23 \times 13,338=$ 109,771.74 rubles., Young horses $-5,38 \times 3420=399.6$ rubles. Total: $109,771.74128,171.34+=18399.6$ rubles.

Comparing these results with the data in Table 4 it is to be noted that the financial performance has improved significantly. Therefore, the management decision to optimize the production program was made correctly. Removal from production of horse meat will improve the financial position of koumiss farm and will lead to increasing the profits by 5557.50 rubles $(128,171.34$ - 122,613.84) per month. Average annual income may increase by 66,690 rubles.

\section{Conclusions}

Thus, the need in integration of various elements of management accounting in a single system, supporting cost-considered management decision making, increase of productivity and competitiveness, is obvious in the current economic environment for effective management of agricultural enterprise and its existence in strict competitive environment, including the international level. In practice, some elements of management accounting, as a rule, are used in enterprises. It is important that these elements should be combined into the overall structure, aimed at achieving a specific result. Management accounting system, which is one of the most effective tools for planning and forecasting, operational control of efficiency of enterprise resources use, increase of its attractiveness, is a greatly complicated diverse system characterized by unity and correlation with external environment, structure, hierarchy, permanence in functioning and evolution, orientation to purpose, etc.

\section{References}

Bebbington, J., \& Thomson, I. (2013). Sustainable development, management and accounting: Boundary crossing. Management Accounting Research, 24(4), 277-283. http://dx.doi.org/10.1016/j.mar.2013.09.002

Bourne, M., Melnyk, S. A., Bititci, U., Platts, K., \& Andersen, B. (2014). Emerging issues in performance measurement. Management Accounting Research, 25(2), 117-118. http://dx.doi.org/10.1016/j.mar.2013. 07.002

Ferreira, A., \& Otley, D. (2009). The design and use of performance management systems: An extended framework for analysis. Management Accounting Research, (December), 263-282. http://dx.doi.org/10.1016/j.mar.2009.07.003 
Hopwood, A. G. (2008). Management accounting research in a changing world. Journal of Management Accounting Research, 20, 3-13. http://dx.doi.org/10.2308/jmar.2008.20.1.3

Ittner, C. D., \& Larcker, D. F. (2002). Empirical managerial accounting research: Are we just describing management consulting practice? The European Accounting Review, 11(4), 787-794. http://dx.doi.org/10.1080/0963818022000047082

Janke, R., Mahlendorf, M. D., \& Weber, J. (2014). An exploratory study of the reciprocal relationship between interactive use of management control systems and perception of negative external crisis effects. Management Accounting Research, 25(4), 251-270. http://dx.doi.org/10.1016/j.mar.2014.01.001

Matsui, K. (2013). Entry deterrence through credible commitment to transfer pricing at direct cost. Management Accounting Research, 24(3), 261-275. http://dx.doi.org/10.1016/j.mar.2013.01.001

Nixon, B., \& Burns, J. (2012). Strategic management accounting. Management Accounting Research, 23(4), 225-228. http://dx.doi.org/10.1016/j.mar.2012.09.005

Quinn, M. (2014). Stability and change in management accounting over time-A century or so of evidence from Guinness. Management Accounting Research, 25(1), 76-92. http://dx.doi.org/10.1016/j.mar.2013.06.001

Safiullin, L. N., Klychova, G. S., \& Zakirova, A. R. (2014). Information-Analitical Support of Cost Management in Horse Breeding. Mediterranean Journal of Social Sciences, 5(18), 193-196.

Soin, K., \& Collier, P. (2013). Risk and risk management in management accounting and control. Management Accounting Research, 24(2), 82-87. http://dx.doi.org/10.1016/j.mar.2013.04.003

\section{Copyrights}

Copyright for this article is retained by the author(s), with first publication rights granted to the journal.

This is an open-access article distributed under the terms and conditions of the Creative Commons Attribution license (http://creativecommons.org/licenses/by/3.0/). 